\title{
Review
}

\section{Adam Smith and the circles of sympathy}

\author{
Fonna Forman-Barzilai \\ Cambridge University Press, Cambridge, UK, 2010, 314pp., £55.00, \\ ISBN: 978-0521761123
}

Contemporary Political Theory (2012) 11, e9-e11. doi:10.1057/cpt.2011.8

Fonna Forman-Barzilai's Adam Smith and the Circles of Sympathy is one of the most interesting and beautiful books on Smith I have ever read. Clear, elegant and extremely well argued, the book brings Smith's philosophy to bear thoughtfully on contemporary cosmopolitan projects. I have a few reservations about aspects of the author's view, but on the whole I think there is no better account of Smith and cosmopolitanism, and few books as good on Smith's thought more generally.

Forman-Barzilai argues that Smith picked up the Stoic conception of oikeiosis - that our concern goes out first and foremost to ourselves and those close to us, and then weakens as it moves out, in concentric circles, to our neighbors, country and fellow human beings in general - but rejected the Stoic normative claim that we ought to collapse those circles so that we care equally for everyone, far and near. She analyzes the Stoic roots of Smith's thought carefully, and the aspects of Smith's account of sympathy that led him to adopt the descriptive parts of Stoicism while rejecting its normative elements. She then asks where this leaves Smith in relationship to the cosmopolitanism advocated by contemporary philosophers and political theorists. To figures like Martha Nussbaum and Amartya Sen, who have hailed Smith as an ancestor of their own cosmopolitan projects, she urges caution. As FormanBarzilai explains them, the workings of sympathy and the impartial spectator, for Smith, do not readily allow for an extension of our moral commitments to human beings very distant from us; she draws an incisive distinction between affective and historical or cultural bias, and brings out superbly why Smith's impartial spectator is far better at correcting for the former than the latter (pp. 176-183).

If we want to find sources in Smith's thought to underwrite a cosmopolitan moral view, Forman-Barzilai recommends that we turn to Smith's conception of trade as bringing people together, and to his conception of justice. As she rightly notes, Smith took our revulsion against cruelty to be the source of our rules of justice, and in this she sees a kinship between Smith and the minimal

(C) 2012 Macmillan Publishers Ltd. 1470-8914 Contemporary Political Theory Vol. 11, 3, e9-e11 www.palgrave-journals.com/cpt/ 
cosmopolitanism of Judith Shklar, for whom a general human revulsion against cruelty can unite us against at least the worst violations of our common humanity: genocide, torture and other gross violations of human rights. However, Forman-Barzilai adds a surprising twist to this point. The revulsion against cruelty to which Smith appeals as a basis for this justice, she says, works outside of and in good part against the 'apparatus of sympathy' in which Smith rooted the rest of morality (pp. 234-237). It thereby escapes the threat of cultural relativism that haunts Smith's account of sympathy, and of the impartial spectator by which we are supposed to guide our sympathies.

I am very sympathetic to Forman-Barzilai's conclusions, but I think she overestimates the degree to which a bare, unsocialized revulsion to cruelty can serve as a foundation for universal principles of justice. Forman-Barzilai makes a powerful case for the importance of our revulsion against cruelty. Nothing more than such an instinctive horror is needed to condemn massacre and gross brutality, and this may indeed be enough to support a worldwide resistance to such atrocities as the Nazi Holocaust or the mass murders conducted by Idi Amin and Pol Pot. It is also true, as Forman-Barzilai notes (pp. 228, 232-233), that attempts to base a universal conception of justice on anything much thicker than this - on a substantial conception of the good, especially - are likely to foster either endless controversy or the imposition of one vision of the good, by those with power, on everyone else.

However, universal justice surely consists of far more than a prohibition of genocide and torture. Smith certainly understood it that way. His attempt to draw out 'general principles which ought to run through and be the foundation of the laws of all nations' (Theory of Moral Sentiments VII.iv.37; pp. 341-342) extended to rules for property and contract and marriage and punishment, and in the Wealth of Nations, he used the word 'justice' at least as much to describe the protection of property and contractual obligations, or the fairness of systems of taxation, as to underwrite a standard of humane treatment that might, say, rule out slavery and the brutality that went with European colonialism. However, arbitrary or lax rules of property and contract, and inequitable modes of taxation, although they may well inflict considerable harm on people, are hardly the sort of gross cruelty to which all human beings have an instinctive revulsion. Indeed, most of the harms that we normally regard as injustices cannot be so much as defined properly without reference to complex systems of social norms - are not something which it is plausible to suppose that everyone, everywhere, will see as harms. Even slavery, shorn of the brutality that usually comes with it, need not on its own appear as obvious cruelty, nor do oppressive forms of marriage, or the suppression of free speech and the freedom of religion. Smith wants, laudably, to condemn all such practices, and he attempted in his Lectures on Jurisprudence to work out principles on which they could be condemned, but it is difficult to imagine how

e10 (C) 2012 Macmillan Publishers Ltd. 1470-8914 Contemporary Political Theory Vol. 11, 3, e9-e11 
an appeal to an unsocialized reaction to cruelty could underwrite such principles. Nor is it easy to see how the human rights discourse we need today, even to promote quite minimal standards of decency and freedom across the world, can be grounded in a revulsion to harms that human beings recognize independently of discourse and socialization. If we want to uphold a universal right of conscience, for instance, we will do better to try to make clear what we see as valuable about it in detailed, thick terms - to make the case, even to those with whom we otherwise differ over the ultimate human good, that everyone should be able to choose freely how to pursue that good - than to appeal merely to a pre-cultural, instinctive hatred of cruelty.

I therefore think Forman-Barzilai has at most grasped one important aspect of Smith's account of justice in her emphasis on the supreme importance of avoiding cruelty, and one manner in which that aspect of Smith may enrich contemporary discussions of cosmopolitanism. I would put greater emphasis than she does on other aspects of Smith: on the importance of actually visiting distant others (for commerce, or for other purposes), for instance, and the value of literature and other appeals to the imagination in helping us understand others. However, these are in the end quibbles. For FormanBarzilai's most important point in this marvelous book is to bring out the serious obstacles in the manner of achieving the cosmopolitan dream that so many people today entertain, and the ways in which Smith can help us recognize and negotiate these obstacles. For this project, and the sobering correction it offers to the work of many other political theorists, we are very much in her debt.

Sam Fleischacker University of Illinois at Chicago, Chicago, Illinois 60607, USA 